\title{
Examining the Relationship among Online Brand Elements, Dialogic Communication and Online Brand Personality
}

\author{
Rhodalene Amartey \\ Ghana Institute of Journalism, Ghana. P. O. Box 667, Accra.
}

\begin{abstract}
The objective of this study is to assess the relationship among online brand elements, dialogic communication and brand personality. The study used survey research design. The unit of analysis was the universities in Ghana. Descriptive statistics, confirmatory factor analysis and logistic regression were used to analyze the data. The findings show that brand and website elements significantly influence three brand personality dimensions namely: competence, excitement, and sophistication. The findings also revealed that websites with high dialogic communication features would significantly enhance the relationship between brand and website elements and the university brand personality dimensions as compared to those with low dialogic communication features.

Keywords: brand personality, brand elements, dialogic communication, logistic regression, universities in Ghana
\end{abstract}

DOI: $10.7176 / \mathrm{EJBM} / 11-3-05$

\subsection{Introduction}

Ghana's tertiary sector has undergone rapid changes in the last decade. With the introduction of private universities, increase in enrolment, upgrading image and reputation and attaining a good rank coupled with the increasing competitive environment, product innovations and globalisation have led to a situation where the battle for customers is tense. In order to rise to the challenge, many universities in Ghana are now offering one or more forms of electronic services to their customers. This can be attributed to the rapid rise in technology and the limitations that the traditional form of branding also known as offline branding pose. Technology especially the worldwide web features offer organisations and marketers, an attractive and competitive platform to showcase their organisations' products and services to the world at large as well as overcome the limitations of offline branding.

Research has shown that organisations which have adopted branding have made remarkable strides and therefore gained a competitive advantage over their competitors (see Che-Ha, Nguyen, Yahya, Melewar \& Chen, 2016; Brodie, Benson-Rea \& Medlin, 2017). Consequently, recent studies are being investigated to advance branding concepts within the university sector (Ali-Choudhury, Bennett \& Savani, 2009), such as brand as an image (Chapleo, 2007), a logo (Alessandri, Yang \& Kinsey, 2006), brand differentiation, brand personality (Rutter, Lettice \& Nadeau, 2017), brand awareness, brand identity (Lynch, 2006), brand associations (Opoku, 2005), brand meaning (Teh \& Salleh, 2011) and brand consistency (Alessandri et al., 2006).

In recent times, online branding which is a new phenomenon has been readily accepted and embraced by many organisations as a catalyst that spearheads an organisation's competitive advantage (repetitive statement) (Barreda, Bilgihan, Nusair \& Okumus, 2016; Bilgihan, 2016). Generally, online branding is seen as a critical factor to the success of an organisation and though organisations know about the performance benefits of its adoption and integration, research suggests that brands are unsure of how to manage their online strategy and in turn achieve positive outcomes (Hanna, Rohm, \& Crittenden, 2011). Universities are therefore no exception, with disorderly online campaigns and misaligned strategies which ultimately hinder the potential for cultivating relationships with potential students (Constantinides \& Zinck Stagno, 2011).

Also, notwithstanding the essential role of interactivity in the online media, available research offers conflicting results. A stream of research supports the view that increased levels of interactivity in a web environment are positively related to effective advertising results such as formation of positive attitude toward consumer behaviour (Sundar and Kim, 2005). However, another stream of research postulates that enhanced levels of interactivity are associated with negative effects on the online communication process such as limited process of the provided information (Bezjian-Avery, et al., 1998). Therefore, using dialogic communications to examine interactivity, this study sheds light on the above discrepancies and clarifies the role of interactivity on website effectiveness. Dialogic communications studies have examined the implementation of dialogic strategies in social media sites (Rybalko \& Seltzer, 2010), teaching and learning (Mercer \& Howe, 2012), organisational website (Romenti, Murtarelli, \& Valentini, 2014) in influencing stakeholder behaviour.

However, it remains unclear whether the interactive nature of dialogic strategies is more effective than nondialogic ones in promoting online brand personality.

A review of the extant literature on online branding indicates it is now being championed by several scholars in brands management. Previous studies conducted have focussed on either one of the constructs or on the integration of two constructs typically: Online branding and dialogic principles. However, most of these 
research studies have been conducted within the context of a developed economy, therefore the fact that this study is within a developing economy context' is not justifiable enough unless the specific nature of the economy significantly impacts on the constructs and the interrelationships. This study therefore seeks to add to knowledge by introducing a third construct which is "brand personality" thereby integrating three constructs in a single study and making the research richer.

Online website features (Rowley, 2009), dialogic interrogation of websites (Okoe et al 2015) and brand personality (Liao et al, 2015, Aaker 1997) have been studied separately creating the impression that they fall within separate disciplines. Some few studies conducted within developing countries context also focused on only the dialogic (interactive) aspects of websites (Hinson, Madichie \& Ibrahim, 2012) and brand personality offline (Rutter et al 2016). Waters and Tindall (2010) went a step further by applying the dialogic principles to online communication of organisations but did not examine brand personality. Rutter et al (2016) also conducted a study on brand personality of academic prospectus but not the brand personality of academic websites. Brand personality of Nike sports shoes users have also been studied but was done offline. (Liao, Chung \& Yi Lin, 2015)

This study therefore seeks to fill the research gap by integrating dialogic principles, brand and website features and brand personality constructs in a single study and not as separate units as done by previous studies. The aim is to discuss the relationships among the three constructs for creating an acceptable online branding environment: brand and website features and brand personality; and the moderation.

This study uses three constructs namely: (1) brand and website features with (2) dialogic communications principles (3) online brand personality. Online brand personality creates a branding environment that is not only important but influences and reinforces or adjusts a positive behaviour towards a brand (Kim \& Lehto, 2012). Yet, very few studies have examined the brand and website features in examining destination personality. Most of these studies conducted have focused on online retail (Leen, Ramayah \& Omar, 2010; Shobeiri, Laroche, \& Mazaheri, 2013) and destination marketing (Chi, Pan \& Del Chiappa, 2018), leaving other sectors untreated.

\subsection{Literature Review}

\section{Online branding and its elements}

Online branding has been defined as "how online channels are used to support branding". (Chaffey 2008). To Rowley $(2009,2004)$, online brand simply defined is "a brand that has an online presence". Rowley identified the following as the elements of online brand: Logo,

Graphics, Text and copy, Currency and news, Shapes, Layout and combination of images, Relationship features. A recent study in online branding has been conducted by Ishtiaq and Siddiqui (2016) in their article "branding by Islamic banks in Pakistan: a content analysis of visual brand elements" The study looks at brand elements used by Islamic bank in Pakistan on their websites. Content analysis was the research instrument used in obtaining on the brand elements of five established banks and fourteen conventional banks offering Islamic Windows (IWS). Source of the data was the official websites of the banks deemed as relevant. Findings show that the brand elements have been used by the IBs and IWs to the optimum. However, a few recommendations were made to further enhance the banks' strategies for branding. Even though this study used content analysis it was still limited. This study therefore fills the methodological gap by adding a survey to solicit information on users' perspective of the universities' websites and also to analyze online brand elements and not offline as proposed by Rowley (2009).

In a study of online branding strategies of UK fashion retailers, Rowley (2009) explored the use of online channels to support brands. The study performed a content analysis on the websites of several top fashion and clothing retailers, including three supermarket chains with a huge presence in clothes retailing. The study analyzed the extent to which retailers employed the website to deliver online services and further provided a data led analysis of online branding, online branding strategies regarding the communication of branding identity and brand relationship building. The study found that leading "nonvalue' fashion retailers provide transactions through their websites, delivering further opportunities for brand experience and engagement. The study revealed that though fashion retailers are able to achieve synergy in terms of visual identity between the online and other channels, deploying the online channel to propagate brand values, and to communicate brand relationships is yet to be fully developed. The implication is that there is room for considerable improvement of the concepts of online branding. Gaps therefore exist in the online and multi-channel branding literature for researchers to contribute to.

\subsection{Dialogic Communications}

The term "dialogue" was not originally introduced in the seminal work of "I and Thou" of Buber as it was professed. However, it was rather introduced in an essay titled

"Dialogue" in 1965 with the aim of elaborating on the principle of human life with emphasis on "I and Thou". That is the two-fold orientation that describes human encounters with other human beings and nature. 
According to Piecka (2010) "dialogue" was initially within the purview of psychology. Subsequently, the study of "dialogue" has adopted a multidisciplinary approach and this has led to much debate since the 1990's (Piecka, 2010). Some of the definitions have changed the meaning of the word "dialogue" and therefore that brought to light the different aspects of history (Wieizbicka, 2006). Wieizbicka identifies 8 key characteristics of dialogue. These characteristics are as follows:

- Dialogue is a process which goes on for some time, not continuously but in separate episodes.

- Dialogue is a group activity prototypically involving two groups and it is reciprocal consists in talking about a particular range of topics-presumably topics of mutual interest;

- Dialogue involves participants who are aware of their differences: it also means that the participants fully recognise the importance of the subject matter to both parties and that it is emotionally laden: both parties go through some form of emotional experience when they think about issues of this kind.

- Dialogue is not just an exchange of ideas, it does not just relate to knowing what is on the mind of the other party but comprehending how they think and being also understood oneself;

- Dialogue involves participants who do not necessarily seek to revolve all differences between the different parties and ensuring a similar thinking to the point but rather it is expected that the two parties will find common ground by maybe clarifying other respective positions;

- Dialogue calls for deposition of respect and goodwill;

- Dialogue requires that participants refrain from criticizing the other party which would otherwise kill the dialogue;

- Dialogue is perceived by participants as valuable and effective in itself. In the course of the dialogue, the two parties will discover issues that they at least agree on which may change their thinking on some points (Wierzbicka 2006 pp 689-90).

It is worth noting that scholars and practitioners of dialogue have differences with the features of dialogue but not major disagreements. This is because some scholars focus on the dialogue features and not on the specific definitions used (Piecka, 2010). However, Kent and Taylor (2001) provided a framework based on the integration of five principles: usefulness of information on websites, ease of use, conservation of visitors, return visits and dialogic loop. The principles have been discussed below:

Usefulness of Information: This discusses how organisations make important information available to all stakeholders in a logical rational and hierarchical manner.

Ease of Use: Organizations should develop websites that users can easily understand and navigate (Kent \& Taylor, 2004)

Conservation of Visitors: For a website to function effectively, it must have features and links that will compel visitors to the site to surf for a considerable time.

Generation of Return Visits: It maintains that websites should foster long term relationships by providing features that encourage return visits.

Dialogic Loop: Stakeholders should be allowed to query, interact or offer suggestions to the organization for improvement in its services.

The existence of the first four principles facilitates the websites interactivity whilst the fifth principle which is the dialogic loop contains the actual dialogic feature. Kent and Taylor (1998) therefore sum it up by stating that the web gives organizations the chance to firm up their relationships with the public such that the dialogic loop is embedded in the communication of the organization. Based on this theory it will be useful to establish whether the websites of Universities are dialogic or not? Furthermore, it would be useful to examine if the interactive nature of the website enhances the relationship between brand and website features and building of brand personality.

De Oliveria and Huertas (2014) studied dialogic communication in Brazilian websites from a longitudinal perspective. The objective of the study was to analyze the use of dialogic tools on Brazilian websites in two periods 2010 and 2011. Drawing from previous studies and dialogic communication in a different context, the study employed content analysis methodology to achieve the research objectives. Using search engines on the internet (google, yahoo and Bing), a final sample of 137 sites of internship organizations were selected as a representative sample. With respect to the content analysis an encoder was adopted and adapted from studies conducted into the use of dialogic tools in American universities websites. The encoder divided the various items of dialogic communications into four dimensions namely dialogic loop, Intuitiveness/ease of interface, usefulness of information and generation of return visits. These dimensions formed part of Kent and

Taylor's (1998) original dialogic principles. The study found that companies had low use of dialogic tools and have not optimized its use to engage students' attraction to achieve loyal audience. Similar to general studies conducted on dialogic communications of organizations websites, the focus was on content analysis from the firm's perspective. It therefore ignores what other stakeholders are saying about the firm's websites. Therefore, 
this study intends to fill the gap by incorporating the users' perception of the websites.

Koehler (2014) studied dialogue and relationship building in online financial communications. The study explores the use of social media in investor communications from the perspective of the securities and exchange communications (SEC) in the United States and Europe. The study admitted that online dialogue poses a greater challenge despite the fact that the spread of online information is widespread. Relying on the extant literature, a distinction was established between dialogue oriented and dialogic communication processes.

Dialogic communication was espoused as only serving as a means for building relationships with stakeholders. Focusing on the 150 largest global cooperating listed in the security and exchange communications in the United States, France, United Kingdom, Japan and Germany a content analysis was employed to investigate their websites and external platforms. Twitter, Facebook, YouTube, Google, Linkedin, Slideshare StockTwits, Flicker and Retail Investor Conferences (RIC). The study found that only few corporations globally boast of tools containing feedback options on their websites or empty external social media to respond to user comments and handle criticism in an open manner. United States large corporations were found to be most dialogic on both websites and external social media platforms. There are however limitations with regard to methodology and scope. The study was limited to top companies in major financial market. Other sectors of the economy as well as developing countries context will also have to be considered. While quantitative content analysis resulted in an in-depth analysis of specific cases, it was limited only to analysis of outcomes of communication process from the perspective of organizations. This study will not limit itself to the organizations but also critically look at the stakeholders.

\section{Brand Personality}

Brand personality is deeply rooted in Marketing and Psychology. According to the seminal work of Aaker (1997), brand personality is a "set of human traits associated with the product" Brand personality helps consumers to associate themselves with the brand to express their own personality through the brand (Su \& Ting, 2015). Aaker's framework postulated five dimensions that cut across all product categories. These are competence, excitement, ruggedness, sincerity and sophistication. My study adopted these 5dimensional elements of brand personality to measure the brand personality of the universities in Ghana.

\subsection{Conceptual Framework}

Figure 1 presents the model tested in this study. As shown in figure 1, students perceived brand and website features level is proposed as a significant antecedent of university website personality. The interactive nature of the website which is examined using the dialogic communication principle is proposed to be a critical determinant of the strength of the relationship between brand and website features and university website personality.

The following are the hypotheses developed based on the literature review:

H1. Perceived brand and web elements positively impact customer perceptions of the university website personality dimension.

H2. University website brand personality formation are stronger when the web site design is dialogic principlesbased.

\section{Figure 1 Conceptual Framework: Online Branding Environment}

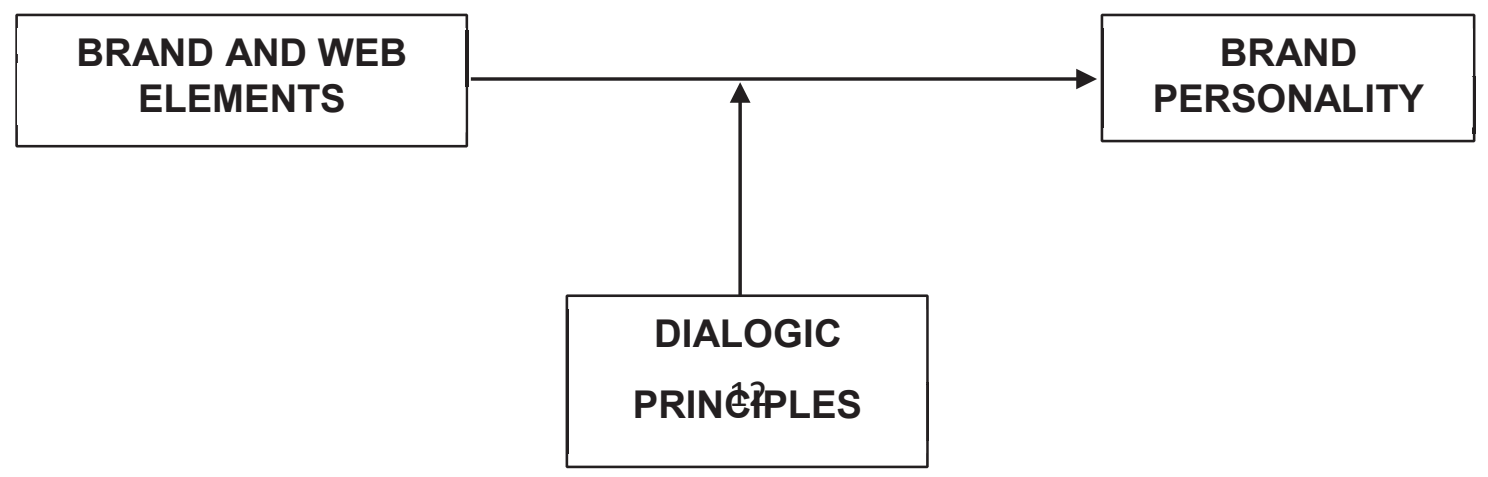

\subsection{Methodology \\ Research design}

A research design is the link between the research questions posed by the researcher and the actual execution of the research (Durkheim). The design is important because it ensures congruency between the research questions, data collection and analysis. Before commenting on the method of study, it is imperative to comment on the research design. 
De Vaus, (2001) also states "research design refers to the overall strategy that you choose to integrate the different components of the study in a coherent and logical way, thereby, ensuring you will effectively address the research problem; it constitutes of the blueprint for the collection, measurement, and analysis of data".

This study is a survey and therefore is non-experimental in nature. The survey is a method used in quantitative research to collect information with respect to characteristics, opinions, attitudes and experiences of people. According to Leedy \& Ormod (2005), a survey is a method used by researchers to take a snapshot in a particular time of a specific group of people having a specific experience. Croucher \& Cronn-Mills (2015), also posits that "a survey is a social scientific research method in which respondents are asked certain questions about their own or other individuals' attitudes, behaviours, beliefs, perceptions and or values." This research is therefore quantitative in nature because based on the extant literature, the study proposes to study how universities are branding themselves online, how dialogic their websites are and their brand personality. It also seeks to establish the relationship among three constructs: online branding, dialogic communications, brand personality and its impact on each other.

The nature of the research problem determines that a survey design be employed in the current study through the administration of a questionnaire. Through a questionnaire, the research collected new data and information from respondents who responded to specific questions. Again, a survey design was used for the study because respondents were drawn from the various universities. The findings will contribute to the body of knowledge in brand management and dialogic communication.

This study used primary data. Primary sources are usually defined as first-hand information or data that is generated by witnesses or participants. Primary data constitutes field data collected from students who use the websites of the various universities. Primary data is collected specifically for the purpose of solving a current research problem (Money and Samuel 2003). The study of online branding elements, dialogic principles and brand personality require original data in order to provide answers to the research problem. Primary data was used because of the exploratory and descriptive nature of the proposed study. It also established new ways of providing theoretical explanation to experts of branding. The primary data was collected from students of the various universities respectively through questionnaire administration. The instruments used are captured in tables 2 and 3.

\subsection{Research Population and Sample}

Population is a total collection of elements which researchers wish to make some inferences according to Bloomberg, Cooper, \& Schindler (2011). Out of the 73 accredited

Universities, the population for this study were students from the sixty-five (65) accredited universities in Ghana with functional websites during the sampling time frame (see appendix for list). Despite the potential bias arising from the reported demographic skew, "the adoption of undergraduate student samples for exploratory factor-analytical work is widespread in marketing research" (Brakus et al., 2009).

Therefore, between a minimum sample size of 360 and a maximum of 900 was deemed appropriate for this study. To obtain this sample size, this study made use of a combination of non-probability sampling techniques such as quota and convenience. A quota size of 100 was assigned to the nine (9) randomly sampled universities. Convenience sampling was also used to select only university students who fall within the stipulated target group.

\subsection{Data Analysis}

This study used descriptive statistics, confirmatory factor analysis (CFA) and logistic regression. The descriptive statistics was used to analyze the demographic data of the respondents. CFA was used to test whether the measures of a construct are consistent with the researcher's understanding of the nature of that construct or factor. The objective of CFA was to test whether the data fit the hypothesized model which is based on theory and previous analytical research. The study established whether most of the independent variables have significant influences on the dependent variable. Logistic regression was employed in the hypotheses of this thesis given that the outcome variables of brand personality was measured as a dichotomous/binary measure. According to Cochran's (2018) "logistic regression is a statistical method for analyzing a dataset in which there are one or more independent variables that determine an outcome and the outcome is measured with a dichotomous variable (in which there are only two possible outcomes)". Therefore, this analysis was appropriate for examining the relationships.

\subsection{Demographic Information}

Table 1 below shows that respondents were of a nearly equal number of male $(50.6 \%)$ and female $(49.4 \%)$ with $86.9 \%$ aged 25 or under, from a wide variety of Ghanaian public universities. However, three institutions i.e. Ghana Institute of Journalism, University of Professional Studies Accra and University of Education, Winneba accounted for $54.5 \%$ of the respondents. Furthermore, $56.2 \%$ of the respondents have been in their respective universities for not more than a year and nearly half of the respondents $(47.8 \%)$ visited the university website at 
least once a month.

Table 1 : Demographic variable

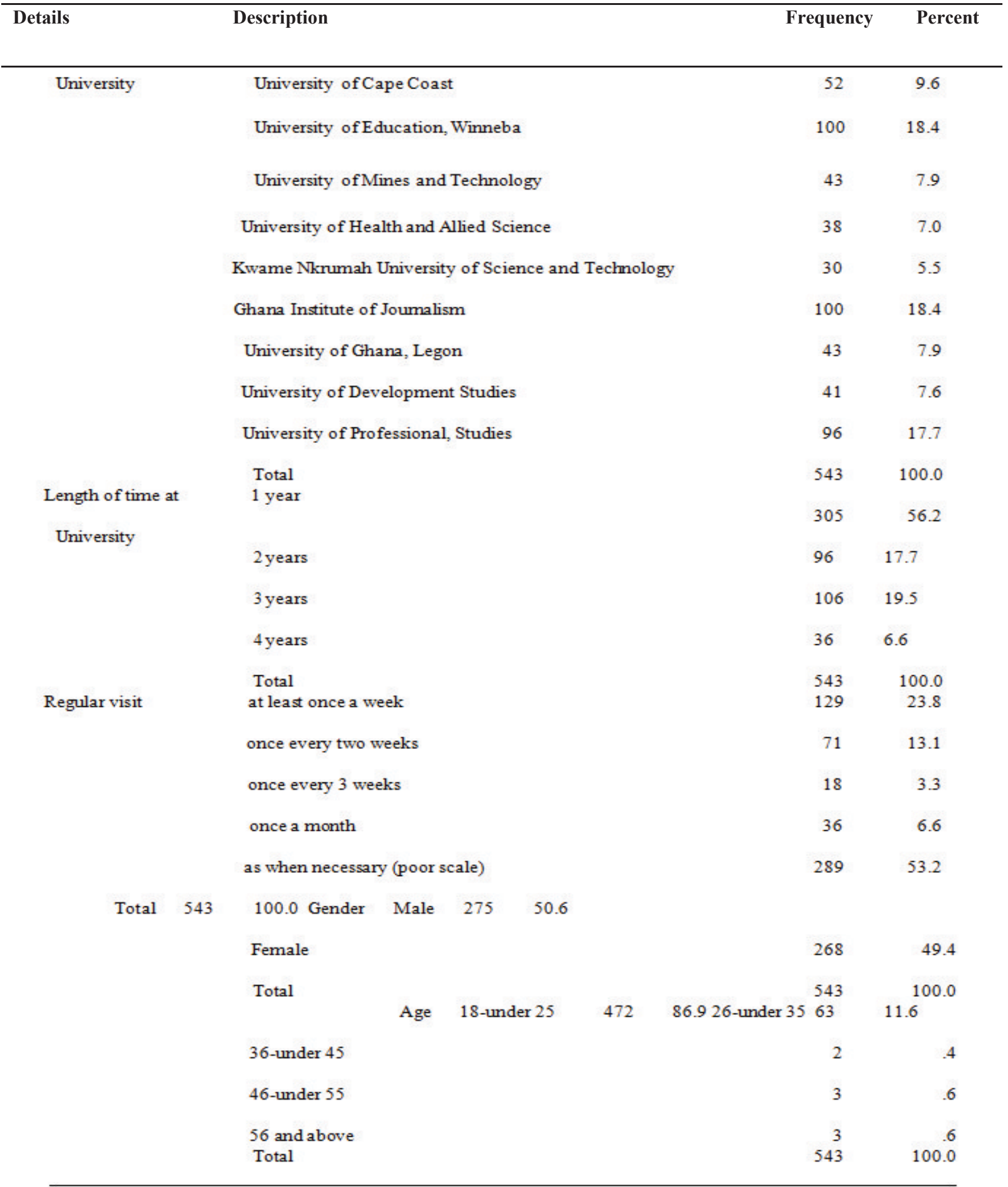

\subsection{Descriptive Statistics}

An overview of key descriptive statistics of the brand and website elements and the dialogic communication features, including mean, standard deviation (i.e., SD), skewness and kurtosis scores is presented in Table 2 and 3. The findings reveal that the most prevailing factors text and copy, graphics and layout and combination of message which had most of the items having a mean greater than 3, where 3 neither agree nor disagree. Also, most of the dialogic communication principles seem to be prevalent apart from the site's dialogical loop items. 
Table 2: Descriptive analysis of brand and website elements

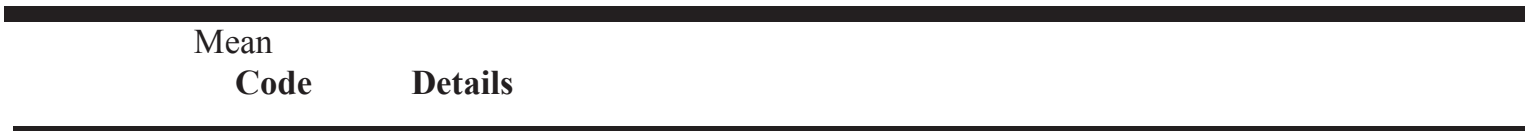

\section{LOGO}

BLO1 The university's logo has been prominently displayed on their home page

BLO2 Aside the home page I have noticed the university's logo at other

$\begin{array}{lccl}2.73 & 1.277 & -1.089 & .151 \\ & & & \\ 2.92 & 1.189 & -.869 & -.107 \\ & & & \\ & & & \\ 3.47 & 1.258 & -.654 & -.557 \\ 3.73 & 1.189 & -.063 & -.862 \\ 3.62 & 1.215 & -.370 & -.722 \\ & & & \\ 3.83 & 1.111 & .463 & - \\ & & & 1.003 \\ 3.51 & 1.125 & -.342 & -.523 \\ 3.42 & 1.279 & -.779 & -.470\end{array}$

There is a type face on the university's website
BT3 My university consciously welcomes and invites users to its websites places on their website

\section{GRAPHICS}

BG1 The university has several pictures on its website

BG2 Aside the pictures the university has other images on its website

BG3 The university has its logo at several areas on the website

\section{TEXT AND COPY}

BT1 My university uses words on its home page

\section{CURRENCY AND NEWS}

BC1 My university updates its website regularly

$\mathrm{BC} 2$ Information provided on the website is very current

\section{LAYOUT AND COMBINATION OF MESSAGE}

BL1 The overall layout of the website communicates a university setting to me

\section{RELATIONSHIP FEATURES}

BR1 The university has e-mail facility on its website

$\begin{array}{llll}3.52 & 1.239 & -.663 & -.571 \\ 3.61 & 1.111 & -.171 & -.683 \\ 3.47 & 1.173 & -.516 & -.566 \\ & & & \\ 3.65 & 1.222 & -.360 & -.716 \\ 2.96 & 1.282 & -1.026 & -.049 \\ 3.16 & 1.229 & -.891 & -.310 \\ 3.03 & 1.195 & -.810 & -.112 \\ & & & \\ 3.30 & 1.230 & -.817 & -.370 \\ 2.92 & 1.243 & -1.036 & -.081 \\ & & & \\ 2.90 & 1.190 & -.892 & -.058\end{array}$

BR7 Navigating the website is very fast i.e. less than 4 seconds

in less than $1 / 2$ a 
Table 3 : Descriptive analysis of dialogic communication features

\begin{tabular}{llrrrr}
\hline Code & \multicolumn{1}{c}{ Details } & Mean & $\begin{array}{l}\text { Std. } \\
\text { Deviation }\end{array}$ & \multicolumn{2}{c}{ KurtosisSkewness } \\
\hline & EASE OF INTERFACE- NAVIGATION OF THE WEBSITE & & & \\
DE1 & The website's main link is located on the home page & 3.54 & 1.131 & -.147 & -.645 \\
DE2 & $\begin{array}{l}\text { The university's website provides a search engine } \\
\text { DE3 }\end{array}$ & 3.55 & 1.139 & -.266 & -.643 \\
& I find it easy to search for data on the website & 3.31 & 1.148 & -.685 & -.347 \\
TE4 & $\begin{array}{l}\text { The university's website has a site map that offers quick and direct route } \\
\text { for answers to specific questions }\end{array}$ & 3.16 & 1.165 & -.697 & -.220 \\
DE5 & $\begin{array}{l}\text { The website has low reliance on graphics which helps to expedite loading } \\
\text { time }\end{array}$ & 3.08 & 1.079 & -.409 & -.216
\end{tabular}
USEFULNESS OF SITE

DU1 The website provides a statement of the university's philosophy The website provides information on calendar of event for the university

DU2 activities The site provides information on how to open an account with the

DU3 university The site provides frequently asked questions (FAQ) or a Question and

DU4 Answer (Q\&A)

DU5 The university post news item on its website The news item on the website can be downloaded e.g. weekly bulletins,

DU6 newsletters

DU7 The university logo is prominently displayed on the site

DU8 The website links to like- minded organisations

\section{THE SITE'S DIALOGICAL LOOP}

DS1 It is possible to email the university from the site

DS2 It is possible for shareholders to vote from the site (membership polls)

DS3 It is possible to subscribe to the university's $\mathrm{e}^{\text {-news letter }}$

DS4 The site provides a forum for visitors to chat with one another The site offers a forum that could be used to provide feedback to the

DS5 university

\section{WEBSITE'S ABILITY TO CONSERVE ITS VISITORS}

DW1 The home page has important information about the university in the following

DW2 Address

DW3 Working hours

DW4 Information on buying university product

DW5 Loading time of less than 4 seconds

DW6 Date of the site's last update $\begin{array}{lll}2.82 & 1.069 & -.322\end{array}$

$2.81 \quad 1.050 \quad-.303 \quad .053$

$\begin{array}{llll}2.72 & 1.143 & -.601 & .143\end{array}$

$\begin{array}{llll}3.59 & 1.173 & -.413 & -.626\end{array}$

$\begin{array}{llll}3.66 & 1.208 & -.277 & -.792\end{array}$

$\begin{array}{llll}3.00 & 1.201 & -.842 & -.052\end{array}$

$\begin{array}{llll}3.14 & 1.179 & -.786 & -.178\end{array}$

$\begin{array}{llll}3.50 & 1.189 & -.569 & -.548\end{array}$

$3.19 \quad 1.166 \quad-.703 \quad-.269$

$3.67 \quad 1.126-.165 \quad-.719$

$3.21 \quad 1.138-.628 \quad-.253$

$3.08 \quad 1.164 \quad-.641 \quad-.201$

$\begin{array}{lllll}3.67 & 1.204 & -.287 & -.759\end{array}$

$\begin{array}{llll}3.33 & 1.267 & -.869 & -.351\end{array}$

$\begin{array}{llll}3.02 & 1.173 & -.678 & -.119\end{array}$

$\begin{array}{llll}2.96 & 1.179 & -.775 & -.071\end{array}$

$\begin{array}{llll}3.17 & 1.213 & -.762 & -.209\end{array}$

$\begin{array}{llll}3.04 & 1.098 & -.460 & -.126\end{array}$ 


\section{GENERATION OF RETURN VISITORS}

DG1 The website has an explicit statement inviting visitor's return

DG2 There is a book mark feature available on the website

DG3 The website's users are able to request information from the organization

DG4 The university website has been updated in the last 30 days

According to Hair, Hult, et al. (2014), academics should know that extremely skewed data can diminish the measurable force of the examination. As a result, an evaluation of normality was done using skewness and kurtosis before testing the hypothesised relationship. Table 5.2 and 5.3 above revealed that the skewness and kurtosis are within the acceptable limits of \pm 2 as recommended by scholars (Fidel, 2000; George \& Mallery, 2003; Gravetter \& Wallnau, 2014; Trochim \& Donnelly, 2006). The findings in Table 2 and 3 show that the data was normally distributed.

\subsection{Measurement Model Assessment}

Before examining the hypothesis, the reliability and validity of the measurement items were assessed. Reliability which is the consistency of a measure items was evaluated based on the consistency across items (internal consistency) via composite reliability and Cronbach's alpha (Hair et al., 2016). Support is provided for internal consistency when each item composite reliability and Cronbach's alpha is greater than 0.7 (Cronbach \& Meehl, 1955; Hair et al., 2016). This provided evidence of measurement item reliability as seen in Table 4.

Validity on the other hand "is the extent to which the scores from a measure represent the variable they are intended to" (Price, Chiang, \& Jhangiani, 2015). In this study, two forms of validity were examined: (1) criterion validity; and (2) discriminant validity. Criterion validity is "the extent to which people's scores on a measure are correlated with other variables (known as criteria) that one would expect them to be correlated with" (Price, Chiang, \& Jhangiani, 2015). Therefore, this study assessed via loading of scores using SEM-PLS confirmatory factor analysis (CFA) outer loadings.

Confirmatory factor analysis (CFA) "is a statistical technique used to verify the factor structure of a set of observed variables and it allows the researcher to test the hypothesis that a relationship between observed variables and their underlying latent constructs exists" (Suhr, 2006). According to Hair et al. (2016) loadings of observed variables (measurement items) should be greater than 0.5 to provide evidence of criterion validity. For this study, all measurement item outer loadings were greater than the recommended 0.5 therefore the items were deemed validity in terms of criterion (see Table 4). 
Table 4: Confirmatory factor analysis (CFA)

Details Loadings Composite Reliability Cronbach's Alpha

Logo

\section{BLO1}

BLO2

Graphics

BG1

BG2

BG3

Text and copy

BT1

BT2

BT3

Currency and news

BC1

$\mathrm{BC} 2$

Layout and combination of message

Relationship features

BR3

BR4

BR6

BR7

BR8

Ease of interface

DE1

DE2

DE3

DE4

DU3

DU4

DU5

DU6

DU8

DS1

DS2

DS3

DS4

DS5

Website ability to conserve visitors

DW1

DW2

DW3

DW4

DW5

DW6

DG1

DG2

DG3

DG4
0.734

0.725

0.772

0.747

0.682

0.827

0.691

0.737

0.78

$0.838 \quad 0.758$

0.727

0.704

0.683

0.756

$0.876 \quad 0.820$

0.583

0.841

0.854

0.795

0.735
0.750

0.810

0.749

0.726

0.864

0.810

0.889
0.728

0.707

1.000 . 
PLS) it is advisable to use square-root value of AVE to compare with corresponding correlation values with other variables (Hair et al., 2014) because of its sensitivity to overestimate indicator/item loading (Hui \& Wold 1982; Lohmöller 1989). The diagonals in Table 5 represented the square root of the AVE and the correlations among constructs. The correlations among the constructs are less than the square root of the AVE, an indication of discriminant validity.

Table 5: Discriminant Validity

\begin{tabular}{|c|c|c|c|c|c|c|c|c|c|c|}
\hline Details & 12 & 3 & 4 & 5 & 6 & 7 & 8 & 9 & 10 & 11 \\
\hline 1 Currency and news & 0.795 & & & & & & & & & \\
\hline 2 Ease of interface & $0.393 \mathbf{0 . 7 3 8}$ & & & & & & & & & \\
\hline $\begin{array}{l}3 \text { Generation of return } \\
\text { visitors }\end{array}$ & 0.2670 .342 & 0.755 & & & & & & & & \\
\hline 4 Graphics & $\begin{array}{lll}0.381 & 0.31\end{array}$ & 0.268 & & & & & & & & \\
\hline 5 Layout and combination & 0.4070 .307 & 0.272 & $\begin{array}{l}\mathbf{0 . 7 6 6} \\
0.301\end{array}$ & 1.000 & & & & & & \\
\hline 6 Logo & 0.2400 .233 & 0.270 & 0.213 & 0.237 & 0.894 & & & & & \\
\hline 7 Relationship features & 0.3980 .415 & 0.365 & 0.284 & 0.308 & 0.298 & 0.733 & & & & \\
\hline 8 Site dialogical loop & 0.2270 .269 & 0.510 & 0.224 & 0.160 & 0.237 & 0.431 & 0.768 & & & \\
\hline 9 Text and copy & 0.4200 .341 & 0.305 & 0.600 & 0.341 & 0.256 & 0.343 & 0.181 & 0.749 & & \\
\hline 10 Usefulness of site & 0.4010 .472 & 0.508 & 0.345 & 0.306 & 0.270 & 0.531 & 0.530 & 0.328 & 0.713 & \\
\hline $\begin{array}{l}11 \text { Ability to converse its } \\
\text { visitors }\end{array}$ & 0.3440 .366 & 0.537 & 0.288 & 0.273 & 0.212 & 0.444 & 0.495 & 0.316 & 0.480 & 0.719 \\
\hline
\end{tabular}

\section{Logistic Regression}

In evaluating brand-specific personality among the respondents, as well as examining the predictive power of the brand and website elements, logistic regressions were conducted. The brand and website elements were used as the predictor variables in each of the brand personality dimensions. The dependent variable of the brand personality dimensions was the agreedisagree binary segments of brand personality dimensions.

\section{Direct Relationship}

In Table VI, the brand personality dimension (competence, excitement, ruggedness, sincerity and sophistication) were keyed as selection variables to determine brand-specific personality dimensions likelihoods based on university website. Each of the four sorted models - competence $(X 2=3.471, d f=1, p$ value $=.047)$, excitement $(\mathrm{X} 2=4.079, \mathrm{df}=1, \mathrm{p}$ value $=.043)$, ruggedness $(\mathrm{X} 2=2.635, \mathrm{df}=1, \mathrm{p}$ value $=.105)$, sincerity $(\mathrm{X} 2=2.472, \mathrm{df}$ $=1, \mathrm{p}$ value $=.116)$ and sophistication $(\mathrm{X} 2=7.632, \mathrm{df}=1, \mathrm{p}$ value $=.006)$.

Table 6: Logistic regressions with likelihood ratio tests on brand personality

\begin{tabular}{lccccr}
\hline Details & B & Wald & Df & Sig. & $\operatorname{Exp}(\mathrm{B})$ \\
\hline Competence & .168 & 3.471 & 1 & .047 & .871 \\
Excitement & .176 & 4.050 & 1 & .044 & .839 \\
Ruggedness & .140 & 2.617 & 1 & .106 & 1.150 \\
Sincerity & .136 & 2.461 & 1 & .117 & .873 \\
Sophistication & .246 & 7.513 & 1 & .006 & .782 \\
\hline
\end{tabular}

From the analysis, the findings of the study showed that brand and website elements significantly influence three brand personality dimensions namely: competence, excitement, and sophistication.

\section{Moderation}

In order to assess the moderating effect of dialogic communication on the relationship between university branding and website elements and brand personality, K-means cluster analysis was used in dividing categorized respondents into websites exhibiting high and low dialogic communication levels. Also, the brand personality element of university website (competence, excitement, and sophistication) were computed as a single dimension. 
Table 7: Logistic regressions (high vs low dialogic communication)

\begin{tabular}{|c|c|c|c|c|c|c|}
\hline & Details & $\mathrm{B}$ & Wald & $\mathrm{df}$ & Sig. & $\operatorname{Exp}(B)$ \\
\hline High & Brand Personality & .168 & 3.471 & 1 & .047 & .871 \\
\hline Low & Brand Personality & .484 & 10.549 & & & 1 \\
\hline
\end{tabular}

The findings revealed that websites with high dialogic communication features would significantly enhance the relationship between brand and website elements and the university brand personality dimensions as compared to those with low dialogic communication features.

\section{Discussions and conclusions}

Drawing on the study objective, hypothesis and conceptual model for the study, the next discussion focuses on the relationship between brand and website elements and brand personality. Literature has established that websites can have website brand personality (Chi, Pan \& Del Chiappa, 2018). This study builds on the stream of research by investigating the impact of brand and website elements on website personality.

This study examines how brand and website elements, affected each of the five elements of brand personality. The findings support that currency and news, graphics, layout and combination, logo, relationship features, and text and copy of a university website result in the brand personality dimensions of competence, excitement, and sophistication. Contrary to expectations, the data did not support that website brand personality results in ruggedness and sincerity.

In sum, this research showed that the competence, excitement, and sophistication dimension of university website personality could be improved by providing certain brand and website elements on the site. This finding is consistent with previous works that showed that certain website elements could be improve in enhancing website brand personality (Shobeiri, Laroche \& Mazaheri, 2013; Chi, Pan, \& Del Chiappa, 2018). This study confirmed the major role of website as extension of an organisation brand with brand elements that improve of this website personality dimension.

Consequently, to the earlier discussion, this segment seeks to evaluate the influence of interactivity on the relationship between brand and website elements and brand personality. In order to do this, the study examined the differences between websites with high and low dialogic communication elements in terms of the strength of impact of brand and website elements on brand personality. The findings show that, website with high dialogic communication elements have a stronger relationship between brand and website elements on brand personality as compared with website with low dialogic communication elements. One possible explanation may be that websites with high dialogic communication elements have increasing engagement with customers which enable the building of brand personality based on the brand and website elements.

\section{References}

Aaker, J. L. (1997). Dimensions of brand personality. Journal of marketing research, 347-356.

Alessandri, S. W., Yang, S. U., \& Kinsey, D. F. (2006). An integrative approach to university visual identity and reputation. Corporate Reputation Review, 9(4), 258-270.

Ali-Choudhury, R., Bennett, R., \& Savani, S. (2009). University marketing directors' views on the components of a university brand. International Review on Public and Nonprofit Marketing, 6(1), 11-33.

Bezjian-Avery, A., Calder, B., \& Iacobucci, D. (1998). New media interactive advertising vs. traditional advertising. Journal of advertising research, 38, 23-32.

Bilgihan, A. (2016). Gen Y customer loyalty in online shopping: An integrated model of trust, user experience and branding. Computers in Human Behavior, 61, 103-113.

Bilgihan, A., Barreda, A., Okumus, F., \& Nusair, K. (2016). Consumer perception of knowledge-sharing in travel-related online social networks. Tourism Management, 52, 287-296.

Bloomberg, B., Cooper, D. R., \& Schindler, P. S. (2011). Business Research Methods, 3rd European Edition.

Brodie, R. J., Benson-Rea, M., \& Medlin, C. J. (2017). Branding as a dynamic capability: Strategic advantage from integrating meanings with identification. Marketing Theory, 17(2), 183-199.

Chaffey, D. Wh. (2008). What is online branding?, available at: www.davechaffey.com/ E-marketing-Glossary

Chapleo, C. (2007). Barriers to brand building in UK universities?. International Journal of Nonprofit and Voluntary Sector Marketing, 12(1), 23-32.

Che-Ha, N., Nguyen, B., Yahya, W. K., Melewar, T. C., \& Chen, Y. P. (2016).

Country branding emerging from citizens' emotions and the perceptions of competitive advantage: The case of Malaysia. Journal of Vacation Marketing, 22(1), 13-28.

Chi, C. G. Q., Pan, L., \& Del Chiappa, G. (2018). Examining destination personality: Its antecedents and outcomes. Journal of Destination Marketing \& Management, 9, September, 149-159

Constantinides, E., \& Zinck Stagno, M. C. (2011). Potential of the social media as instruments of higher education marketing: a segmentation study. Journal of marketing for higher education, 21(1), 7-24. 
Croucher, S. M., \& Cronn-Mills, D. (2014). Understanding communication research methods: A theoretical and practical approach. Routledge.

De Oliveira, M. J., \& Huertas, M. K. Z. (2014). Dialogic Communication in Brazilian Websites: A Longitudinal Study. XVII SEMEAD Seminários em Administração. Available at: www.sistema.semead.com.br

Gravetter, F. J., \& Wallnau, L. B. (2014). Introduction to the t statistic. Essentials of Statistics for the Behavioral Sciences, 8, 252.

Fornell, C., and Larcker, D. F. (1981). Evaluating structural equation models with unobservable variables and measurement error. Journal of Marketing Research. 39-50.

George, D., \& Mallery, P. (2003). SPSS for window Step by Step. Boston, MA.

Hair Jr, J. F., Hult, G. T. M., Ringle, C., \& Sarstedt, M. (2016). A primer on partial least squares structural equation modeling (PLS-SEM). Sage Publications, UK.

Hanna, R., Rohm, A., \& Crittenden, V. L. (2011). We're all connected: The power of the social media ecosystem. Business horizons, 54(3), 265-273.

Hinson, R. E., Madichie, N. O., \& Ibrahim, M. (2012). A dialogic communications interrogation of the online brand dispositions of banks operating in Ghana. International Journal of Bank Marketing, 30(7), 508-526.

Hui, B. S., \& Wold, H. (1982). Consistency and consistency at large of partial least squares estimates. Systems under indirect observation, part II, 119-130.

Ishtiaq, S. M., \& Siddiqui, K. A. (2016). Branding by Islamic Banks in Pakistan: A Content Analysis of Visual Brand Elements. Journal of Marketing Management and Consumer Behavior, 1(2). 1, 33-44

Kent, M. L., \& Taylor, M. (1998). Building dialogic relationships through the World Wide Web. Public relations review, 24(3), 321-334.

Kim, S., Ee \& Lehto, X. Y. (2012). The voice of tourists with mobility disabilities: insights from online customer complaint websites. International Journal of Contemporary Hospitality Management, 24(3), 451476.

Koehler, K. (2014). Dialogue and relationship building in online financial communications. International Journal of Strategic Communication, 8(3), 177-195.

Leedy, P. and Ormrod, J. (2001), Practical Research: Planning and Design, Prentice-Hall, Upper Saddle River, NJ.

Leen, J., Ramayah, T., \& Omar, A. (2010). The impact of website personality on consumers' initial trust towards online retailing websites. World Academy of Science, Engineering and Technology, 66, 820-825.

Liao, S. H., Chung, Y. C., \& Lin, K. Y. (2015). A clash of personality? The relationship among consumer personality, brand personality and word-of-mouth with social-cognitive perspective: generation as the moderator. International Journal of Services Technology and Management, 21(1-3), 111-126.

Lohmöller, J. B. (1989). Latent variable path modeling with partial least squares. Heidelberg, Germany: PhysicaVerlag

Mercer, N., \& Howe, C. (2012). Explaining the dialogic processes of teaching and learning: The value and potential of sociocultural theory. Learning, culture and social interaction, 1(1), 12-21.

Okoe, A. F., Boateng, H., Quansah, F., \& Omane, A. B. (2015). Self Esteem, Customer Identification and Willingness to Pay Price Premium: Evidence from Young Consumers Market. Asian Journal of Marketing, 9(1), 27-37.

Opoku, R. A. (2005). Communication of brand personality by some top business schools online. Unpublished thesis, Lulea University of Technology.

Price, P. C., Chiang, I. C. A., \& Jhangiani, R. (2015). Research methods in psychology. BCcampus, BC Open Textbook Project.

Romenti, S., Murtarelli, G., \& Valentini, C. (2014). Organisations' conversations in social media: applying dialogue strategies in times of crises. Corporate Communications: An International Journal, 19(1), 10-33.

Rowley, J. (2009). Online branding strategies of UK fashion retailers. Internet Research, 19(3), 348-369.

Rutter, R., Roper, S., \& Lettice, F. (2016). Social media interaction, the university brand and recruitment performance. Journal of Business Research, 69(8), 3096- 3104.

Rutter, R., Lettice, F., \& Nadeau, J. (2017). Brand personality in higher education: anthropomorphized university marketing communications. Journal of Marketing for Higher Education, 27(1), 19-39.

Rybalko, S., \& Seltzer, T. (2010). Dialogic communication in 140 characters or less: How Fortune 500 companies engage stakeholders using Twitter. Public relations review, 36(4), 336-341.

Shobeiri, S., Laroche, M., \& Mazaheri, E. (2013). Shaping e-retailer's website personality: The importance of experiential marketing. Journal of retailing and consumer services, 20(1), 102-110.

Sundar, S. S., \& Kim, J. (2005). Interactivity and persuasion: Influencing attitudes with information and involvement. Journal of interactive advertising, 5(2), 5-18.

Taylor, M., \& Kent, M. L. (2004). Congressional web sites and their potential for public dialogue. Atlantic Journal of Communication, 12(2), 59-76. 
Taylor, M., Kent, M. L., \& White, W. J. (2001). How activist organizations are using the Internet to build relationships. Public Relations Review, 27(3), 263-284.

Teh, G. M., \& Salleh, A. H. M. (2011). Impact of brand meaning on brand equity of higher educational institutions in Malaysia. World, 3(2), 218-228.

Trochim, W., \& Donnelly, J. P. (2006). The research methods knowledge base (3rd ed.). Retrieved from www.socialresearchmethods.net/kb/index.php

Waters, R. D., \& Tindall, N. T. (2010). Marketing churches on the Internet: an analysis of the dialogic potential of Christian web sites. International Journal of nonprofit and voluntary sector marketing, 15(4), 369-381.

Wierzbicka, A. (2006). The concept of 'dialogue'in cross-linguistic and crosscultural perspective. Discourse Studies, 8(5), 675-703.

\section{PROFILE OF MRS RHODALENE AMARTEY}

Mrs. Rhodalene Amartey is a seasoned lecturer and a researcher with an insatiable desire for knowledge and ready to impart to others. She holds a Bachelor's degree in Sociology and a Masters' degree in Business Administration (Marketing Option) respectively from the

University of Ghana. She also holds a professional marketing qualification from the Chartered Institute of Marketing, UK. Currently, she is a final year Doctoral student (PhD) in Business Administration at the Accra Institute of Technology, a private university affiliated with the

Open University in Malaysia 